SUSTAINABLE FORESTRY

COLLECTION 81-82, 2020
ODRŽIVO ŠUMARSTVO

ZBORNIK RADOVA 81-82, 2020

UDK $630 * 81+674.038 .1=111$

Original scientific paper

\title{
POTENTIALS OF THE ASSESSMENT OF THE WOOD QUALITY IN STANDING TREES BY APPLYING ACOUSTIC METHODS
}

\author{
Ivana ŽIVANOVIĆ ${ }^{1}$, Nebojša TODOROVIĆ ${ }^{2}$, Ljubinko RAKONJAC , \\ Filip JOVANOVIĆ ${ }^{1}$
}

\begin{abstract}
Based on literature sources, the stress wave and ultrasound methods and tools designed for the evaluation of the effects of decay on wood are discussed in this paper. To make a review of the results obtained in numerous studies, the analytic-synthetic method was used and the evaluation of data was conducted. The results revealed high correlations between the measured properties and the actual wood quality. A number of studies show that the acoustic wave velocities correlate well to wood density and other wood properties. Changes in the acoustic velocity and wood density variations caused by decay have also been detected successfully using the ultrasonic tools. This means that wood quality can be assessed in situ and that the methods and devices in question can help us make the right decisions. Still, it must be pointed out that all the methods and devices used are only measuring and quantifying tools, and practical human experience cannot be replaced by any measuring tools.
\end{abstract}

Keywords: acoustic methods, wood properties, wood quality, non-destructive wood investigation, wood production

\section{MOGUĆNOSTI PROCENE KVALITETA DRVETA DUBEĆIH STABALA PRIMENOM AKUSTIČNIH METODA}

Izvod: Na osnovu literaturnih izvora, u radu su razmatrane akustična tomografija i ultrazvučna metoda, kao i sprave koje su namenjene ispitivanju efekata koje trulež ima na

\footnotetext{
${ }^{1}$ B.Sc. Ivana Živanović, Dr. Ljubinko Rakonjac, Dr. Filip Jovanović, Institute of Forestry, 3 Kneza Višeslava, 11030 Belgrade, Serbia.

${ }^{2}$ Prof. Dr. Nebojša Todorović, Faculty of Forestry, 1 Kneza Višeslava, 11030 Belgrade, Serbia

Author for correspondence: B.Sc. Ivana Živanović, Institute of Forestry, 3 Kneza Višeslava, 11030 Belgrade, Serbia, +381628838069, e-mail: ivana.radovanovic1712@gmail.com
} 
svojstva drveta. Kako bi se načinio pregled rezultata dobijenih u brojnim istraživanjima, primenjen je analitičko-sintetički metod sa procenom podataka. Rezultati pokazuju dobru korelisanost između analiziranih svojstava drveta i njegovog kvaliteta. Tako, mnoga istraživanja pokazuju dobru korelisanost između brzine zvučnih talasa i gustine drveta, kao i ostalih njegovih svojstava. Promene u brzini zvučnih talasa i varijacije u gustini drveta koje su izazvane truležima su isto tako uspešno detektovane primenom ultrazvučnih instrumenata. Ovo znači da se kvalitet drveta može proceniti in situ $i$ da opisane metode i sprave mogu doprineti boljem odlučivanju u praksi. Ipak, neophodno je istaći da sve metode i sprave predstavljaju samo pomagala za merenje $i$ ispitivanje svojstava drveta $i$ da se praktično iskustvo stručnjaka ne može nadomestiti nikakvim mernim istrumentima.

Ključne reči: akustične metode, svojstva drveta, kvalitet drveta, nedestruktivno ispitivanje drveta, prerada drveta

\section{INTRODUCTION}

As a natural material, wood has been used for different purposes since ancient times. At present, wood is utilized as a raw material in the industry of different products (e.g., furniture, structure timber for buildings, various wood-based panels, pulp, and paper), being an irreplaceable raw material for some of these products. According to Marković et al. (2015) development of the wood processing industry is causing a growing demand for high-quality wood raw materials. In fact, due to its organic origin and renewability, wood is one of the most sought-after natural materials today (Živanović et al., 2019).

Owing to its natural origin, wood shows a large variation in properties that mostly depend on the cellular, anatomical, and chemical characteristics of wood (Šoškić, 2002). The properties of wood highly condition the application of wood final products, as well as their economic value. This is the prime reason for the grading of wood based on its properties. In most cases, sorted wood is graded visually, with no science background. However, this method of wood property assessment is not always acceptable, due to its unreliability and subjectivity. Much more reliable methods should be used to assess the properties of wood, especially those properties reflecting the interior structure of wood which is difficult to assess visually. In recent years, great efforts were made in wood science and technology to develop non-destructive methods and tools for a more accurate assessment of wood properties of standing trees (Živanović et al., 2019). Mechanical, acoustic, and radiation methods have been developed for this purpose. These methods investigate properties of wood in situ, without destruction. This way, science and practice are provided by significant data regarding the properties and quality of wood, while the wood consumption is minimized (Todorović, 2014).

The paper presents two acoustic methods for the assessment of wood quality in standing trees. The stress wave and ultrasound methods, as well as tools designed for the evaluation of the effects of decay on wood, based on wood acoustic properties, are discussed thoroughly in the paper from the point of view of costefficient production in wood-processing.

Acoustics is a popular way to estimate stiffness in standing trees with simple, compact, and easy to use devices (Dickson et al., 2004). Instruments for this purpose 
usually measure the speed of waves or sound traveling through the wood. There are two ways for assessing the internal condition of wood using sound - by using ultrasound and sound waves. The main difference between them is that the ultrasonic wave is generated by sound pulses of known frequency, while the voltage of the sound wave is not known. Given that wood is a solid medium, the speed of the wave in it is much higher than in air and depends on the type of wave and the elasticity and density of the material. Damaged wood often results in a modified speed of propagation of the acoustic wave, so that the propagation time of the sound wave provides useful information about the mentioned properties of wood (Goh et al., 2018).

\section{MATERIAL AND METHODS}

The analytic-synthetic method was used as a basic method in the paper. Prior to the analytical procedure, it was necessary to collect, evaluate, select, systematize, and update information about the methods studied. The evaluation of literature data collected was based on simple, practical, but also some complex indicators. The purpose of the paper was to make a review of the results obtained in numerous papers.

The collected literature data, related to the potentials for applying acoustic methods and tools for the assessment of the wood quality in standing trees, have been carefully studied and classified into several groups:

1. Literature data related to the theoretical definitions, purpose, and practical application of the methods and tools;

2. Literature data comprising comparative tests with other nondestructive methods for the evaluation of the quality of wood in standing trees;

3. Literature data comprising the results of the same methods applied to different tree species.

\section{RESULTS AND DISCUSSION}

In order to promote timber value, it is fundamentally important to study the characteristics of forest management options in more detail. To avoid unintentional loss of wood quality when selecting trees for high productivity in tree breeding programs, acoustic methods are among the most useful methods for efficient and reliable assessment of wood quality in standing trees. This is demonstrated by the results obtained in numerous studies. The results of the studies that are considered the most notable are presented in Table 1.

Mahon (2007) obtained acoustic velocities from 100 standing loblolly pine (Pinus taeda L.) trees with the transmitting and receiving probes placed on the sameface and opposite-faces, and by comparing the results using FAKOPP's TreeSonic. In this study, significant differences in velocity between the two methods were found. Variation in velocities from hit-to-hit was $62 \%$ less using the opposite-face method compared to the same-face method. In addition to felled tree acoustic velocities, standing tree acoustic velocities were calculated for all six flight paths for 
79 loblolly trees. The author found that acoustic velocity, both in standing and felled trees, increased with age.

Table 1. Selected wood property investigations conducted using acoustic and other non-destructive methods

\begin{tabular}{|c|c|c|c|c|c|}
\hline $\mathbf{N}^{\mathbf{0}}$ & $\begin{array}{l}\text { Method } \\
\text { used }\end{array}$ & Tree species & $\begin{array}{c}\text { Correlation } \\
(r)\end{array}$ & $\begin{array}{l}\text { Property } \\
\text { analyzed }\end{array}$ & Reference \\
\hline 1. & $\begin{array}{c}\text { Acoustic } \\
\text { waves }\end{array}$ & Pinus taeda & Strong & Density & Mahon (2007) \\
\hline 2. & $\begin{array}{l}\text { Acoustic } \\
\text { waves }\end{array}$ & $\begin{array}{c}\text { Cunninghamia } \\
\text { lanceolata }\end{array}$ & $\begin{array}{l}0.77 \\
0.57 \\
0.45\end{array}$ & Various & Yin et al. (2010) \\
\hline 3. & $\begin{array}{l}\text { Acoustic } \\
\text { waves }\end{array}$ & Pinus radiata & $\begin{array}{c}\text { Strong } \\
\text { negative }\end{array}$ & $\begin{array}{c}\text { Longitudinal } \\
\text { shrinkage }\end{array}$ & Chauhan et al. (2013) \\
\hline 4. & $\begin{array}{c}\text { Acoustic } \\
\text { waves } \\
\text { Pylodin } \\
\text { penetration }\end{array}$ & Picea abies & $\begin{array}{c}-0.96 \\
-0.94 \\
0.99\end{array}$ & $\begin{array}{l}\text { Density } \\
\text { Microfibril } \\
\text { angle } \\
\text { Modulus of } \\
\text { elasticity }\end{array}$ & Chen et al. (2015) \\
\hline 5. & $\begin{array}{c}\text { Acoustic } \\
\text { waves } \\
\text { (SWV) } \\
\text { Pylodin } \\
\text { penetration } \\
\text { (PP) }\end{array}$ & Larix decidua & $\begin{array}{c}0.56 \\
(\mathrm{SWV}) \\
0.32-0.61 \\
\text { (PP) }\end{array}$ & $\begin{array}{l}\text { Modulus of } \\
\text { elasticity }\end{array}$ & Škorpík et al. (2018) \\
\hline 6. & $\begin{array}{l}\text { Ultrasonic } \\
\text { method }\end{array}$ & $\begin{array}{c}\text { Pinus caribea } \\
\text { Eucalyptus citriodora } \\
\text { E. grandis } \\
\text { Goupia glabra } \\
\text { Hymenaea } \mathrm{sp} .\end{array}$ & Strong & Density & Oliveira and Sales (2006) \\
\hline 7. & $\begin{array}{l}\text { Ultrasonic } \\
\text { method }\end{array}$ & $\begin{array}{c}\text { Picea abies } \\
\text { Pinus sylvestris }\end{array}$ & $\begin{array}{c}0.663 \\
0.796 \\
\\
0.588 \\
0.5139\end{array}$ & $\begin{array}{c}\text { Bending } \\
\text { strength } \\
\text { Compressive } \\
\text { strength }\end{array}$ & $\begin{array}{l}\text { Dzbeński and Wiktorski } \\
\qquad(2007)\end{array}$ \\
\hline 8. & $\begin{array}{l}\text { Ultrasonic } \\
\text { method }\end{array}$ & Fagus orientalis & Strong & Decay & Kazemi-Najafi et al. (2009) \\
\hline 9. & $\begin{array}{c}\text { Ultrasonic } \\
\text { method } \\
\text { X-ray }\end{array}$ & $\begin{array}{c}\text { Picea abies } \\
\text { Populus deltoides }\end{array}$ & Strong & $\begin{array}{l}\text { Reaction } \\
\text { wood }\end{array}$ & Brancheriau et al. (2012) \\
\hline
\end{tabular}

Yin et al. (2010) attempted to establish the method for evaluating wood mechanical properties by acoustic non-destructive testing in standing trees and logs of a Chinese fir (Cunninghamia lanceolata /Lamb./ Hook.) plantation. In addition, they compared three acoustic non-destructive methods for evaluating the static bending modulus of elasticity (MOE), modulus of rupture (MOR), and compressive strength parallel-to-grain $(\sigma \mathrm{c})$ of plantation wood. Static bending tests were then performed to determine the bending MOE and MOR, and compressive tests parallelto-grain were made to determine $\sigma \mathrm{c}$. As determined by the three acoustic methods, the differences between the bending MOE and dynamic MOE of logs were statistically significant $(p>0.001)$. Good correlations $(r=0.77,0.57$, and 0.45$)$ between dynamic modulus of elasticity (DMOE) of a log determined based on stress wave, DMOE of a log determined based on longitudinal vibration, and DMOE of a 
log determined based on the ultrasonic wave, and static MOE, respectively, were obtained $(p>0.001)$. The authors concluded that longitudinal vibration may be the most precise and reliable technique for the evaluation of the mechanical properties of logs among the three acoustic non-destructive methods analyzed. Moreover, the results of the study indicated that stress wave technology would be an effective method for evaluating wood mechanical properties both in logs and standing trees.

El-Kassaby et al. (2011) assessed the genetic control and phenotypic and genotypic correlations among wood density, MOE, height, diameter, and volume for Douglas-fir full-sib families using comparable test sites. They observed significant differences in wood density using two in situ methods (drilling resistance and acoustic velocity). The reliability of the in situ assessments was verified through cumulative pith-to-bark wood density assessment, resulting in inconsistent genetic and phenotypic correlations for early growth years. The latter findings of the study imply that caution should be used in employing these in situ techniques as early screening tools in breeding programs. The authors concluded that significant and consistent genetic correlations between the in situ methods and wood density and stiffness support their use as a non-destructive and economic assessment approach.

Morrow et al. (2013) took standing stress wave measurements from 274 small-diameter Douglas-fir trees in western Montana. Stand, site, and soil measurements were made in this study, and DMOE was determined with a stress wave timer. Several theoretical and logical models were developed to predict DMOE. The authors realized that soil basic density may not be a universally important predictor of wood quality, but future research should consider tree-soil interactions for broad-scale wood quality models.

In the study by Chauhan at al. (2013), opposite wood and compression wood were isolated from the leaning stems and tested for DMOE, density, longitudinal shrinkage, volumetric shrinkage and compression wood area for nursery seedlings of clones of radiata pine (Pinus radiata D. Don) using automated image analysis method and acoustic velocity. Acoustic velocity in opposite wood had a strong negative association with longitudinal shrinkage. Based on the results of the study, the authors concluded that the opposite wood of the clone with the lowest DMOE exhibited the highest longitudinal shrinkage.

Baar et al. (2015) analyzed five tropical hardwoods (Afzelia bipindensis Harms, Intsia bijuga /Colebr./ Kuntze, Millettia laurentii August \& De Wildeman, Astronium graveolens Jacq. and Microberlinia brazzavillensis A. Chev.) of different grain using three non-destructive techniques - longitudinal and flexural resonance method and ultrasound method. The results of their study provided higher values of MOE than the static bending test, but a close correlation was observed between these variables. The weakest correlation was found for the ultrasound method. The authors concluded that the prediction of MOR is less accurate when DMOE is compared with the static MOE. On the other hand, it was still a good prediction in comparison with the density model, and almost all of the correlation coefficients showed the lowest values, although the prediction of MOR by non-destructive techniques was unsatisfactory.

Chen et al. (2015) evaluated the suitability of using Pilodyn penetration (PP) and acoustic velocity to assess wood density, microfibril angle, and MOE of Norway spruce (Picea abies /L./ H. Karst). Strong correlations between Pilodyn 
measurement and wood density $(r=-0.96)$, and between acoustic velocity and microfibril angle $(r=-0.94)$, were detected in this study. The authors found that PP and acoustic velocity measurements from standing trees can provide a reliable prediction of the stiffness of Norway spruce for breeding selection. They realized that traditional methods for the estimation of solid wood quality traits of standing trees, such as wood density, microfibril angle, and MOE, are time-consuming and expensive, which render them unsuitable for rapid screening of a large number of trees in tree breeding programs. The main conclusion of the study was that a combination of PP with Hitman acoustic velocity provides very high selection efficiency for the three most important quality traits of wood mechanical properties of Norway spruce.

Legg and Bradley (2016) made a review on the use of acoustics to measure the stiffness of standing trees, stems and logs. In addition, they reviewed studies that have used acoustic tools to investigate factors that influence the stiffness of trees. These factors included different silvicultural practices, geographic and environmental conditions, and genetics. According to this review, studies using acoustic tools have reported that the initial planting spacing can affect stiffness. The geographic location appeared to play a role in the properties of wood, as well. Genetics also plays a large part in the properties of wood, such as stiffness. The authors concluded that it would be beneficial if any future studies on this topic include more comparisons with other techniques (such as static bending tests) and make a comparison with resonance and stress wave methods.

Dahle et al. (2016) used standard methods to determine static flexural modulus (ES) of elasticity and conducted acoustic testing to estimate DMOE by measuring the speed of sound through a sample of wood without the need to remove any wood samples from northern red oak (Quercus rubra L.). The research investigated whether acoustic testing can be used to accurately estimate MOE of green wood. The authors determined strong correlation coefficient $(0.42)$ between ES and DMOE. DMOE was found to be slightly higher than ES, but simple regression can be developed to predict ES from DMOE for a given species of interest. They concluded that a portable acoustic stress wave system can be used to rapidly estimate DMOE in standing trees.

Proto et al. (2017) used the acoustic velocity time of flight tool to estimate the influence of four thinning treatments performed in Southern Italy. The objective of the study was to determine whether the effects of silvicultural practices on wood quality of Calabrian pine (Pinus nigra Arnold subsp. calabrica) can be identified using the acoustic measurement of DMOE from standing trees. The results showed that tree diameter has a significant influence on acoustic wave measurements and that a valid relationship exists between diameter at breast height and tree velocity. The results proved that the stress wave technique can be successfully applied to standing trees.

Škorpík et al. (2018) tested and applied PP and measured stress wave velocity (SWV) from trees within a European larch (Larix decidua Mill.) breeding program. They found a significant variation of PP and SWV among forest stands, single trees, and even within trees if measured on opposite sides in mountainous terrain. Both measurements exhibited a high degree of genetic determination, i.e., repeatability was $0.32-0.61$ for PP and 0.56 for SWV. The results of the study 
demonstrated that the integration of wood quality parameters into larch breeding programs is highly recommended and that reliable tools are available.

Russo et al. (2019) hypothesized that the tree stand density could influence DMOE and, thus, the future wood quality. They derived DMOE values from data obtained by the acoustic velocity measured with the stress wave timer from Calabrian pine (Pinus brutia Tenore). In this study, a strong positive correlation was observed between the acoustic velocity, the thinning treatments and the diameter at breast height. The thinning realized at $25 \%$ induced better tree wood quality. The authors also analyzed the best predictors for DMOE estimation, using variables easily measurable in the field, such as tree diameter, tree height, or their transformations (number of trees per hectare and basal area per hectare). The results presented a useful tool for predicting the wood stiffness in relation to stand parameters that are easily measurable in forest inventories.

In the research by Llana et al. (2020), acoustic velocity was used to measure 38 standing trees and resonance velocity was recorded in green logs made from the trees. The logs were then dried and tested in bending. In addition, estimation models to predict mechanical properties from non-destructive testing measurements were developed. In this study, large differences between velocities obtained by acoustic and resonance techniques were found. Models based on both non-destructive testing velocities together with a species factor were well correlated with bending MOE, while models including tree diameter were moderately correlated with bending strength. The inclusion of density in the models did not improve the estimation. The authors concluded that models based on acoustic measurements from standing trees or resonance from green logs, together with tree species and diameter, provide reliable estimates of mechanical properties of round timber from hardwood thinnings and that the methodology can be easily used for pre-sorting material in forests. For instance, mechanical properties of small-diameter round timber from hardwood thinnings of common alder (Alnus glutinosa /L./ Gaertn.), European ash (Fraxinus excelsior L.), European birch (Betula pendula Roth. and B. pubescens Ehrh.), and sycamore (Acer pseudoplatanus L.) can be evaluated by non-destructive testing in either standing trees or green logs, without wood density determination. Moreover, the authors stated that velocity differences between acoustic and resonance methods are influenced by tree species and age and that the tree diameter improves the estimation of bending strength but not of stiffness.

Oliveira and Sales (2006) investigated the effect of density on the velocity of an ultrasonic wave in wood of Caribbean pine (Pinus caribea Morelet), lemonscented gum (Eucalyptus citriodora /Hook./ K. D. Hill \& L. A. S. Johnson), flooded gum (Eucalyptus grandis W. Hill), kabukalli (Goupia glabra Aubl.) and jatobá (Hymenaea sp.). The study aimed to analyze the influence of density on the longitudinal velocity of an ultrasonic wave, propagated in the longitudinal direction. The relationship between density and velocity was analyzed in two different manners - between and within species. The results obtained between species indicated that ultrasonic velocity tends to increase with increasing density. The results obtained within species also showed an increasing trend in ultrasonic velocity as density increases, but the relationship was not as significant as it was for between species.

Dzbeński and Wiktorski (2007) demonstrated that ultrasonic measurements made both from sawn timber and from standing trees produce satisfactory results in 
predicting certain mechanical properties of sawn timber obtained from the analyzed raw material. In this study, the highest correlation (0.65) was observed between the velocity of ultrasounds along trunks and MOE of sawn timber obtained from them. A similar correlation $(0.60)$ with the bending strength was also satisfactory. Very strong correlations were achieved between longitudinal wave velocity $(r=0.87)$ and transverse wave velocity $(r=0.71)$ in standing trees trunks, and MOE of sawn timber; and parallel correlation coefficients relating to bending strength $(\mathrm{r}=0.66 ; r=0.80)$, and compressive strength $(r=0.59 ; r=0.51)$. In addition, a very strong correlation $(r=0.84, p>0.001)$ between longitudinal ultrasonic velocity in standing tree trunks and sawn timber obtained from same trees provided the basis for the mentioned correlations. The authors concluded that the velocity of ultrasonic wave propagation in coniferous standing tree trunks (pine and spruce) is a good indicator of mechanical properties of sawn timber obtained from them. To ensure the correct interpretation of the results, they recommended that studies should be conducted to detect and locate inner rot in standing tree trunks. They also suggested that the studies could be performed by taking measurements of ultrasonic wave propagation transversely in trunks in a potentially defected area and an area free from defects.

Kazemi-Najafi et al. (2009) used ultrasonic wave timing inspection to detect the internal decay in standing Iranian beech trees (Fagus orientalis Lipsky). The results of this study showed that ultrasonic wave velocity linearly and significantly decreased by increasing hole dimensions, and the location of holes did not influence the extent and trend of velocity decrease. Although slots covered a small volume fraction of disks, they had a great effect on ultrasonic velocity reduction as compared with circular holes.

Brancheriau et al. (2012) studied the effect of reaction wood on ultrasonic wave propagation using tomographic imaging. Reaction wood forms when part of a tree is subjected to mechanical stress and helps to bring parts of the plant into an optimal position. The ultrasonic emission was a pulse train of square waves. Two logs of poplar (Populus deltoides W. Bartram ex Marshall) and Norway spruce were tested because of the presence of different types of reaction wood (tension wood for poplar and compression wood for spruce). In addition to ultrasonic tests, X-ray imaging in transmission was used. The ultrasonic maps were analyzed to highlight the differences between normal wood and observed reaction zones. The X-ray images were also compared to ultrasonic maps. Significant differences were found between normal and reaction wood for both the slowness and the attenuation. Furthermore, poplar and spruce had opposite behaviors. The anatomical and chemical key traits of reaction wood explained these observations. The interaction between moisture content and density highly influenced the ultrasounds/X-rays relationship. The difference of density and moisture content between tension and normal wood did not separate the two groups for poplar. In the case of spruce, the relationships between ultrasonic tomography and X-rays radiography were due to the differences between compression wood and normal wood.

The studies discussed in the present paper revealed high correlations between the measured properties and the actual wood quality. The results show that the acoustic wave velocities correlate well to the density of wood and other wood properties. Changes in the acoustic velocity and wood density variations caused by decay have also been detected successfully using the ultrasonic tools. Similar results 
have also been obtained in our research regarding the use of resistograph and fractometer in wood processing (Živanović et al., 2019).

\section{CONCLUSION}

The present paper aimed to point out the importance of two methods (acoustic and ultrasound) as reliable ways for the assessment of wood defects and quality. Using these methods, decay in wood is discovered in situ. Thus, the methods discussed are recommended for measuring the propagation of acoustic waves through wood of standing trees considering the fact the wave velocity is higher in healthy wood.

Studies discussed in the paper indicate high correlations between the measured properties (MOE, DMOE, Es and $\sigma \mathrm{c}$ ) and the actual wood quality. This means that the quality of wood can be predicted in situ and that the methods described in the paper can help us make the right decisions. This way, science and practice are provided by significant data on the properties and quality of wood, while wood consumption is minimized.

Still, it must be pointed out that all the methods and devices used, including the stress wave timer and ultrasonic tomograph, are only measuring and quantifying tools. The most important of all is the practical experience of the researcher and this will not change in the future because human expertise cannot be replaced by any measuring tools.

\section{REFERENCES}

Baar, J., Tippner, J. and Rademacher, P. (2015): Prediction of mechanical propertiesmodulus of rupture and modulus of elasticity-of five tropical species by nondestructive methods, Ciencia y tecnología, 17(2): 239-252

Brancheriau, L., Saadat-Nia, M. A., Gallet, P., Lasaygues, P., Pourtahmasi, K. and Kaftandjian, V. (2012): Ultrasonic imaging of reaction wood in standing trees, Acoustical Imaging: 399-411

Chauhan, S. S., Sharma, M., Thomas, J., Apiolaza, L. A., Collings, D. A. and Walker, J. C. (2013): Methods for the very early selection of Pinus radiata D. Don. for solid wood products, Annals of Forest Science, 70(4): 439-449

Chen, Z. Q., Karlsson, B., Lundqvist, S. O., Gil, M. R. G., Olsson, L. and Wu, H. X. (2015): Estimating solid wood properties using Pilodyn and acoustic velocity on standing trees of Norway spruce, Annals of Forest Science, 72(4): 499-508

Dahle, G., Carpenter, A. and DeVallance, D. (2016): Non-destructive measurement of the modulus of elasticity of wood using acoustical stress waves, Arboric Urban For, 42: 227233

Dickson, R. L., Matheson, A. C., Joe, B., Ilic, J. and Owen, J. V. (2004): Acoustic segregation of Pinus radiata logs for sawmilling, New Zealand Journal of Forestry Science, 34(2): 175189 
Dzbeński, W. and Wiktorski, T. (2007): Ultrasonic evaluation of mechanical properties of wood in standing trees. COST E 53 conference-quality control for wood and wood products. Warsaw. 15-17

El-Kassaby, Y. A., Mansfield, S., Isik, F. and Stoehr, M. (2011): In situ wood quality assessment in Douglas-fir, Tree Genetics \& Genomes, 7(3): 553-561

Goh, C. L., Rahim, R. A., Rahiman, M. H. F., Talib, M. T. M. and Tee, Z. C. (2018): Sensing wood decay in standing trees: A review, Sensors and Actuators, A: Physical, 269, 276-282

Kazemi-Najafi, S., Shalbafan, A. and Ebrahimi, G. (2009): Internal decay assessment in standing beech trees using ultrasonic velocity measurement, European journal of forest research, 128(4): 345-350

Legg, M. and Bradley, S. (2016): Measurement of stiffness of standing trees and felled logs using acoustics: A review, The Journal of the Acoustical Society of America, 139(2): 588604

Llana, D. F., Short, I. and Harte, A. M. (2020): Use of non-destructive test methods on Irish hardwood standing trees and small-diameter round timber for prediction of mechanical properties, Annals of Forest Science, 77(3): 1-13

Mahon Jr., J. M. (2007): The use of acoustics for the wood quality assessment of standing $P$. taeda trees. PhD Thesis. BSFR, The University of Georgia. Athens

Marković, M., Rajković, S. and Rakonjac, Lj. (2015): Reduction the mechanical properties of oakwood under the influence of epyxilous fungus, Sustainable Forestry, 70-71: 7-17

Morrow, C. D., Gorman, T. M., Evans, J. W., Kretschmann, D. E. and Hatfield, C. A. (2013): Prediction of wood quality in small-diameter Douglas-fir using site and stand characteristics, Wood and Fiber Science, 45(1): 49-61

Oliveira, F. G. R. and Sales, A. (2006): Density effect on ultrasonic velocity in Brazilian wood. Proceedings of the 9th World Conference on Timber Engineering. Portland

Proto, A. R., Macrì, G., Bernardini, V., Russo, D. and Zimbalatti, G. (2017): Acoustic evaluation of wood quality with a non-destructive method in standing trees: a first survey in Italy, iForest-Biogeosciences and Forestry, 10(4): 700-706

Russo, D., Marziliano, P. A., Macri, G., Proto, A. R., Zimbalatti, G. and Lombardi, F. (2019): Does thinning intensity affect wood quality? An analysis of Calabrian pine in Southern Italy using a non-destructive acoustic method, Forests, 10(4): 303-312

Škorpík, P., Konrad, H., Geburek, T., Schuh, M., Vasold, D., Eberhardt, M. and Schueler, S. (2018): Solid wood properties assessed by non-destructive measurements of standing European larch (Larix decidua Mill.): Environmental effects on variation within and among trees and forest stands, Forests, 9(5): 276-289

Šoškić, B. M., Popović, Z. D. and Stanković, P. (2002): The properties of wood. University of Belgrade - Faculty of Forestry. Belgrade (In original: Šoškić, B. M., Popović, Z. D., Stanković, P. (2002): Svojstva drveta. Univerzitet u Beogradu- Šumarski fakultet. Beograd) 
Todorović, N. (2014): Determination of wood quality by non-destructive methods. http://drvotehnika.info/clanci/odredjivanje-kvaliteta-drveta-nedestruktivnim-metodama (accessed on October 7, 2020) (In original: Todorović, N. (2014): Određivanje kvaliteta drveta nedestruktivnim metodama. http://drvotehnika.info/clanci/odredjivanje-kvalitetadrveta-nedestruktivnim-metodama (pristupljeno 7. oktobra 2020))

Yin, Y., Nagao, H., Liu, X. and Nakai, T. (2010): Mechanical properties assessment of Cunninghamia lanceolata plantation wood with three acoustic-based nondestructive methods, Journal of Wood Science, 56(1): 33-40

Živanović, I., Poduška, Z., Rakonjac, Lj. and Jovanović, F. (2019): Potentials of the evaluation of the wood quality in living trees by using semi- and non-destructive methods in order to reduce wood-processing costs, Sustainable Forestry, 78-79: 115-126

\title{
POTENTIALS OF THE ASSESSMENT OF THE WOOD QUALITY IN STANDING TREES BY APPLYING ACOUSTIC METHODS
}

\author{
Ivana ŽIVANOVIĆ, Nebojša TODOROVIĆ, Ljubinko RAKONJAC, Filip JOVANOVIĆ
}

\section{Summary}

At present, wood is an irreplaceable raw material for many products. The properties of wood highly condition the application of wood final products, as well as their economic value. In most cases, sorted wood is graded visually, with no science background. Thus, more reliable methods should be used to assess the properties of wood, especially those properties reflecting the interior structure of wood which is difficult to assess visually. Great efforts have been made in wood science and technology to develop non-destructive methods and tools for the assessment of wood properties in standing trees.

In this paper, two methods (stress wave and ultrasound) and tools designed for the evaluation of the effects of decay on wood, based on wood acoustic properties, are discussed. In order to make a review of the results obtained in numerous studies, the analytic-synthetic method was used and the evaluation of literature data was conducted.

The results discussed in the reviewed studies show that the acoustic wave velocities correlate well to wood density and other wood properties. Changes in the acoustic velocity and wood density variations caused by decay have also been detected successfully using the ultrasonic tools. This way, science and practice are provided by significant data on the properties and quality of wood, while its consumption is minimized.

Still, it must be pointed out that all the methods and devices used, including the stress wave timer and ultrasonic tomograph, are only measuring and quantifying tools of what has already been seen by man. Therefore, the most important of all is the practical experience of the researcher and this will not change in the future because human expertise cannot be replaced by any measuring tools. 


\title{
MOGUĆNOSTI PROCENE KVALITETA DRVETA DUBEĆIH STABALA PRIMENOM AKUSTIČNIH METODA
}

\author{
Ivana ŽIVANOVIĆ, Nebojša TODOROVIĆ, Ljubinko RAKONJAC,Filip JOVANOVIĆ
}

\section{Rezime}

Drvo je danas nezamenljiva sirovina za mnoge proizvode, pri čemu svojstva drveta znatno uslovljavaju primenu finalnih drvnih proizvoda, kao i njihovu ekonomsku vrednost. U većini slučajeva, sortimenti se ocenjuju vizuelno, bez naučne osnove. Stoga je potrebno primeniti pouzdanije metode za procenu svojstava drveta, posebno onih svojstava koja se odnose na unutrašnju građu drveta, koju je teško proceniti spolja. U drvnoprerađivačkoj nauci i tehnologiji uloženi su veliki napori kako bi se razvili postupci i uređaji za određivanje svojstava drveta dubećih stabala na nedestruktivan način.

U ovom radu su razmatrane akustična tomografija i ultrazvučna metoda, kao i sprave koje su konstruisane da utvrde efekte koje trulež ima na svojstva drveta. Da bi se načinio prikaz rezultata koji su dobijeni u brojnim istraživanjima, primenjen je analitičkosintetički metod i izvršena je procena podataka iz literature.

Rezultati koji su predstavljeni u analiziranim radovima pokazuju dobru korelisanost između brzine zvučnih talasa i gustine drveta, kao i ostalih njegovih svojstava. Promene u brzini zvučnih talasa i varijacije u gustini drveta koje su izazvane truležima su takođe uspešno detektovane ultrazvučnim instrumentima. Na ovaj način, nauka i praksa dobijaju značajne podatke o svojstvima i kvalitetu drveta, a utrošak materijala se minimalizuje.

Ipak, neophodno je istaći da sve metode i sprave koje se koriste za opisanu namenu, uključujući akustični tajmer i ultrazvučni tomograf, predstavljaju samo pomagala za merenje i ispitivanje onoga što je čovek već uočio. Stoga, praktično iskustvo stručnjaka ostaje nezamenljivo, što se u budućnosti neće promeniti jer se stručnost istraživača ne može nadomestiti nikakvim mernim instrumentima. 